\title{
AZ ÁLLAMI TÁMOGATÁSOK KETTES TÍPUSÚ ERKÖLCSI KOCKÁZATA
}

Az állami támogatások esetében a vállalatok a vissza nem térítendő forrásból megvalósított fejlesztések esetében, bevétel és nyereséget növekedést realizálnak, ami növeli a társadalmi hasznosságot. Az erkölcsi kockázat az, hogy a vállalatok akkor is elfogadják a támogatást, amikor tudják, hogy a fejlesztésük nem fogja növelni a társadalmi többletet, azaz nem növekszik az értékesítés volumene, nem lesz nagyobb az eredmény, és nem javul a tőkehelyzet, illetve a versenyképessége sem lesz jobb. A tanulmány megvizsgálja, hogy a támogatott vállalkozások betétállomány növekedése tekinthető-e az erkölcsi kockázat megjelenési formájának, amelyet kettes típusú erkölcsi kockázatként azonosít. A vállalati betétállományok gyorsabban növekedtek a támogatási kifizetésben részesült vállalkozások esetében, ami azonban nem tekinthető az erkölcsi kockázat megjelenési formájának, és nem vezethető le egyértelműen a támogatási kifizetések számviteli kimutatásából sem. Ez a hatás a támogatási politika egyik következményeként azonosítható.

Kulcsszavak: EU-támogatások, erkölcsi kockázat

A z Európai Unió tagországai, így Magyarország is közvetlen állami támogatást nyújtanak a vállalatoknak, amelyek ebből a forrásból fejlesztéseket valósítanak meg, bevételnövekedést érnek el, ennek következtében pótlólagos nyereséget realizálnak, ami növeli a társadalmi hasznosságot. A társadalmi hasznosság mérésének egyértelmü módszertana nem áll rendelkezésre, ezért most a vállalat nyereségének növekedését tekintjük az elsődleges megjelenési formának. A kifizetett támogatás a fenntartási időszakban egyéb bevételként jelenik meg, ami a számviteli kimutatásban növeli az eredményt. A támogatásban részesült vállalkozások a már korábban megkapott támogatási összeg adott évre eső részét így tudják elszámolni, ezért a tőkefelhalmozás növekszik, hiszen a támogatott vállalkozások eredménye, eredménytartaléka és ezen keresztül a sajáttőke értéke növekszik. Az állami támogatások ezen a hatásmechanizmuson keresztül eredményezik a támogatásban részesült vállalkozások tőkeerejének növekedését, amelyet szintén társadalmi többletként azonosíthatunk.

Az elmúlt években Magyarországon a KKV-szektor versenyképességének javítása céljából jelentősen nagyobb forrást kapott, mint az európai unióhoz csatlakozott regionális versenytársaink (L. Kállay, 2014). A munkahelyteremtő beruházások révén a foglalkoztatás nőtt, a KKV-szektor jövedelemtermelő képessége azonban nem növekedett azonos mértékben. A hazai gyakorlatban nyilvánvalóan látszik, hogy a KKV-szektor banki finanszírozásának elégtelenségét európai uniós és központi költségvetési forrásbevonási programokkal is javítani igyekeztek. Emellett megfigyelhető volt, hogy mialatt a vállalkozások hitelállománya folyamatosan csökkent, a betétállomány értéke folyamatosan növekedett, és 2016-ra már meg is haladta a hitelállományt.
Amennyiben a vissza nem térítendő támogatásokat az egyébként rendelkezésre álló saját források kiváltására használták és a megmaradt pénzeszközök eredményezték a betétállományok folyamatos növekedését, akkor ez a kettes típusú erkölcsi kockázat következmény lehet. Ha egy vállalkozás a teljes fejlesztési projektet saját erőből képes lenne finanszírozni, de állami támogatásért pályázik, akkor ezt kettes típusú erkölcsi kockázatként azonosíthatjuk. A következőkben megvizsgáljuk, hogy beszélhetünke kettes típusú erkölcsi kockázatról, vagy egyszerüen az erkölcsi kockázat egy lehetséges megjelenési formájával állunk szemben.

A KKV-k finanszírozási problémáinak vizsgálata során külön figyelmet igényel a vissza nem térítendő állami támogatások erkölcsi kockázata, azaz a vállalatok akkor is megpályázzák és elfogadják az ingyenesen forrást, amikor tudják, hogy a fejlesztésük nem fogja növelni a társadalmi többletet. A kereskedelmi banki finanszírozás esetén az erkölcsi kockázat az, hogy a vállalkozás hitelt vesz fel, bár a tervezett fejlesztési projekt jövedelemtermelő képessége nem elégséges ahhoz, hogy a külső forrást képes legyen visszafizetni. A közvetlen állami támogatások nyújtása során a vállalkozás szintén egy meghatározott célra kap forrást, amelyért azonban sem kamatot nem fizet, és a támogatási cél elérése esetén a támogatási összeget sem fizeti vissza. Az állam haszna ebben az esetben az, hogy a nyújtott támogatásért társadalmi többlet keletkezik.

A társadalmi jólét növelése érdekében a GDP közel egy százalékát fordították a tagállamok állami támogatásra, amelynek összege meghaladta Magyarországon a 12 ezer milliárd forintot (European Comission). A támogatások számviteli elszámolásából következik, hogy a fenntar-

\footnotetext{
"A publikáció a Széchenyi 2020 program EFOP-3.6.1-16-2016-00013 "Intelligens szakosodást szolgáló intézményi fejlesztések a Budapesti Corvinus Egyetem székesfehérvári Campusán" című Európai Uniós projektje keretében készült."
} 
tási időszakban az eredmény megnövekszik², aminek következtében az eredménytartalék és a sajáttőke értéke is. A számviteli elszámolás azonban csupán a mérleg forrásoldalát érinti, és nem magyarázza meg az eszközoldalon megfigyelhető változásokat, így a betétállomány növekedési tendenciáját sem. Amennyiben a vállalkozások a kifizetett támogatásokat a hitelek visszafizetésére, valamint a betétállomány növelésére fordították, akkor ez a kettes típusú erkölcsi kockázat következményeként értelmezhető, ami a fejlesztési források nem hatékony felhasználását jelentené. Összehasonlítjuk a betétállományok alakulását az egyes években támogatási kifizetést kapott és nem kapott vállalatok esetében, és a vissza nem térítendő támogatások számviteli elszámolását elemezve következtetek a kettes típusú erkölcsi kockázat igazolhatóságára.

\section{Az erkölcsi kockázat értelmezése}

A KKV-szektorban az erkölcsi kockázat elméleti kutatása a közgazdaságtan csupán néhány publikációjára vezethető vissza (Stiglitz \& Weiss, 1981; Holmstrom \& Tirole, 1997). Az első tanulmány értelmezi az erkölcsi kockázatot, amelyet a hitelfelvevők akciójaként azonosít és ösztönzési hatásnak (incentive effect) nevezi a KKV-finanszírozás terén, még a második egy egységes vizsgálati keretrendszert állít fel. A témával foglalkozó tanulmányok jelentős részben ezekből a feltételezésekből indulnak ki és empirikusan vizsgálják az erkölcsi kockázat jelenlétét. A kontraszelekció és erkölcsi kockázat olyan módon kerülhet empirikusan igazolásra, hogy bizonyos jelenségek jellemző megjelenési formái lehetnek a vizsgált problémának. A leggyakrabban tekintett empirikus vizsgálati cél a hitelkorlát (credit constraint) tesztelése a KKV-finanszírozás során, amelyet a finanszírozás során kontraszelekció következményének tekintenek. A kérdés a jelen vizsgálat során úgy módosul, hogy a vissza nem térítendő állami támogatás esetén a vállalatot mi fogja megakadályozni abban, hogy olyan projektet is megvalósítson, amelyet a csökkenő hozadék miatt önerőből nem valósítana meg.

A KKV-finanszírozás esetén információs aszimmetria és erkölcsi kockázat jellemző, amelyek következtében a piaci tökéletlenség prociklikus (Repullo \& Suarez, 2013), azaz gazdasági visszaesés esetén a kereskedelmi bankok erőteljesebben fogják vissza a KKV-hitelezéseket, ami még sebezhetőbbé teszi a vállalatokat. A KKV-hitelezés élénkítése számos nemzetgazdasági fejlesztési politika célkitűzése, de kérdéses, hogy bizonyos nemzetgazdasági jellemzők esetén mi lesz a hatékony megoldás. Többen megvizsgálják a kereskedelmi banki hitelezési gyakorlatban rejlö lehetöségeket (Beck, Thorsten, Demirgüç-Kunt \& Maksimovic, 2004), tekintik a „Fejlesztési Bankok” kontraciklikus hitelezés ösztönző intézkedéseit (GriffithJones, Tyson \& Calice, 2011), elemzik a KKV menedzsment- és pénzügyi tudásának növelésében rejlö lehetőségeket (Petersen \& Rajan, 1995).
Egységes modellben tárgyalva (Holmstrom \& Tirole, 1997) azt az általános helyzetet vizsgálja, amelyben a vállalatok és finanszírozóik is korlátozott tőkével rendelkeznek, tehát külső forrást kell fejlesztési céljaik eléréséhez igénybe venni. A vállalatok nem rendelkeznek kellő belső megtakarítással, hogy a kívánt méretü beruházási projektet megvalósíthassák, a hitelezők pedig nem tudnak anynyi külső forrást biztosítani, mint amennyit a piac képes lenne felvenni. Ezt a helyzetet nevezzük hitelkorlátosnak, amikor tartósan olyan nem-egyensúlyi állapot jön létre, amelyet a piaci ösztönzők nem képesek megoldani. A hitelezőket a kamatok emelése sem fogja intenzívebb hitelezésre ösztönözni, mert a hitelezők nem hiszik el, hogy a vállalatok képesek nyereséges projekteket indítani, és amennyiben ezeket elindítják, akkor a beruházás erőforrásait kizárólag a projekt érdekében fogják hasznosítani. Ha megvizsgáljuk az állami beavatkozást, hogy az milyen hatást gyakorol a modell szereplöinek ösztönzőire, akkor alapot találhatunk arra, hogy miként tudjuk az állami támogatás hatékonyságát mérni.

A Holmstrom és Tirole (1997) által bemutatott modell, amelyet Berlinger, Juhász és Lovas $(2015,2016)$ továbbfejleszt a közvetlen állami támogatások esetére, azt az általános helyzetet vizsgálja, amelyben a vállalatok és finanszírozóik is korlátozott tőkével rendelkeznek, tehát külső forrást kell fejlesztési céljaik eléréséhez igénybe venniük. Az alapmodellben három szereplő van: a vállalat, a pénzügyi közvetítő és a finanszírozó, akik az első periódusban meghozzák a finanszírozási döntést, szerződést kötnek, a második periódusban pedig elszámolnak egymással. Mindenki kockázatsemleges és korlátozott felelősséggel bír, tehát legfeljebb annyit veszíthet, amennyit az első periódusban kockáztatott. A végtelen számú vállalat azonos módon férhet hozzá a különböző technológiákhoz, az egyetlen különbség a vállalatok között a rendelkezésre álló vagyon, amellyel a tervezett beruházást kívánja megvalósítani, külső forrás bevonása mellett. A kumulált bevétel kudarc esetén a második periódusban nulla, sikeresség esetén pedig nagyobb, mint nulla. A vállalatok megfelelő ösztönzők, illetve ellenőrzés hiányában hajlamosak személyes hasznosságukat (private benefit) növelni, ahelyett, hogy a fejlesztési projekt érdekében tennének meg mindent. A kisebb erőfeszítéssel a projekt sikerességének valószínüségét csökkentik, ami a kereskedelmi banki finanszírozás erkölcsi kockázata. Sikeres projekt esetén nem keletkezik személyes haszon, ám kudarc esetén a vállalat tulajdonosa kicsi, illetve nagy személyes haszonra tehet szert, függően attól, hogy milyen személyes erőfeszítést fejtett ki a projekt megvalósulása érdekében. Itt szembesülünk azzal a fontos kritériummal, hogy a modell szereplöi kockázatsemlegesen viselkednek, ezért ekvivalens számukra, hogy a bizonytalan projekt sikeréből részesedik egy előre meghatározott valószínűséggel, vagy a biztos személyes hasznosságot választja. Amennyiben elvetjük

\footnotetext{
${ }^{2}$ A megnövekedett eredmény azonban nem jelent tényleges többletet, mert nem pénzbeli eredménynövekmény, hanem a hivatkozott számviteli elszámolás következménye.
} 
ezt az egyszerüsítő, de valójában nem reális feltételezést, akkor arra következtethetünk az eredeti modell keretei között is, hogy kockázatkerülö cégtulajdonosok szinte biztosan az egyéni hasznot választják, amennyiben a jövőbeli ellenőrzésből fakadó büntetések kockázatát időben diszkontálni tudják. Amennyiben kockázatkedvelő cégvezetőket sikerül találni, akkor az ő esetükben felmerülhet a beruházás teljes privatizálása, mint „,racionális” kimenet.

A személyes hasznosság attól is függ, hogy sok vagy kevés erőfeszítés történt a projekt sikeressége érdekében. A projekt nem finanszírozható abban az esetben, ha a bevételek jelenértéke és a személyes haszon együtt sem éri el a beruházás elvárt hozamát. Ez a kimenet minden finanszírozó félelme, éppen az aszimmetrikus információeloszlás következtében, hiszen a projektgazda ismeri jobban a projektje és saját preferenciáit. Másképpen fogalmazva, az alacsony erőfeszítés-magas személyes haszon együttes a racionális választás, amennyiben a projekt sikerességének valószínűsége kellően alacsony.

A modell egyértelmű előnye az, hogy egy olyan zárt logikai rendszerben vizsgálja a KKV-finanszírozás egyes kérdéseit, amelyek az alapfeltételezések változtatásán keresztül számos további vizsgálati célt engednek tekinteni. Az erkölcsi kockázat során a modellben egy olyan rejtett akcióval találkozunk, amikor a finanszírozónak nincs elegendő információja a vállalkozó tervezett erőkifejtéséről, ami a vállalkozás és a projekt sikerességének valószínüségét növelni, illetve csökkenteni tudja. A bankok ennek csökkentése érdekében vezetik be a hitelfedezeteket (collateral), azaz amennyiben a vállalat a folyósított hitelt nem képes a nyereséges múködésböl visszafizetni, akkor a bank a vállalat vagyonából fogja követeléseit kielégíteni. Ez egy olyan hatás, amely a vállalatot nagyobb erőfeszítésre ösztönözi, annak érdekében, hogy a projekt sikerességének valószínűsége növekedjen. Az állami támogatások esetén az erkölcsi kockázat az, hogy a vállalat akkor is igénybe veszi az állami támogatást, amikor tudja, hogy az nem fog társadalmi többletet termelni.

Az állami beavatkozást a nemzetközi irodalomban eltérő módon tekintik. Tirole (2009) folytatva a Holmstorm-Tirole hagyományokat az állam szerepét a vállalati hitelezés területén továbbra is a bail-out lehetőségében, azaz a kimentésben látja. A modell elemzési háttere remek alapul szolgálhat a közvetlen állami támogatások hatásmechanizmusainak elemzésére, de hangsúlyozni kell, hogy teljesen mást tekint az állam szerepének. A 2008-as válság gazdaságélénkítő intézkedéseinek részletes elemzése során Vives, (2010) állami támogatásként szintén a közvetítőszektorba pumpált pénzeket tekinti, áttekintést ad az európai bankpiac teljes átrendeződéséről, amelyben a pénzintézetek az erkölcsi kockázatuk csökkentése érdekében átrendezték, illetve eladták és átszervezték a müködésüket. Az állami beavatkozást szabályozás formájában értelmezték, amelyet a verseny és a stabilitás közötti trade-offként határoztak meg.

Olyan elméleti, illetve empirikus irodalmi hivatkozást, amely a KKV-k finanszírozása, az erkölcsi kockázat kezelése és a közvetlen állami támogatások köre területet egyszerre tekintené, nem találtam. Jellemzően olyan publi- kációkat vizsgáltam részletesebben, amelyek kettő terület kombinációját tekintik, azaz a morális kockázat hatásai a KKV-finanszírozásra, illetve a közvetlen állami támogatásra, valamint a közvetlen állami támogatás és a KKVfinanszírozás összevetései. Az állami beavatkozást a nemzetközi közgazdasági irodalom nem a hazai vissza nem térítendő, hanem alapvetően az európai uniós fejlesztéspolitika keretrendszerébe tartozó támogatásokkal azonosítja.

\section{A hazai támogatási és fejlesztési infrastruktúra}

Az állami beavatkozások köre rendkívül széles, ezért nem is beszélhetünk egységesen állami támogatásról. Az állami támogatással kapcsolatos egyik legjelentősebb elvárás az, hogy nem-egyensúlyi helyzetben levő piaci szegmensben alkalmazzák. Ilyen lehet a regionálisan gazdaságilag fejletlenebb területek támogatása, illetve például a KKV-k támogatása, amelyek éppen méretüknél fogva nem tudnak kellő mennyiségben külső forrást felhasználni.

A legjelentősebb nemzetközi statisztikai vizsgálat ebben a témában a Banerjee (2004) volt, amelyben egy bank anonim adatait tudták feldolgozni, majd szegényebb és gazdagabb országok befektetési hozamának vizsgálatával tekintették a banki finanszírozás hatását. Eltérően a banki finanszírozástól, az állami támogatások kedvezményezettek által érzékelt mértéke és annak valós költsége eltérhet, ezért nehéz egy egységes mérőszámban meghatározni a támogatások tényleges hatásait.

A vállalkozás tisztában van a projektje várható jövedelmezőségével, amelyet felülről korlátosnak tekinthetünk, azaz nagy valószínüséggel tudja a vállalkozás, hogy mi az a maximális bevétel és nyereség, amelyet elérhet. Amenynyiben azonban a vállalkozás azt vélelmezi elöre, hogy a projektje nem fog társadalmi többletet generálni, és mégis a megvalósítás mellett dönt, amelyre állami támogatást vesz igénybe, az az erkölcsi kockázat megvalósulása. Sok gazdasági szegmens részesedik rendszeresen állami támogatásból: a magas innovációs igényü fejlesztések, a gazdaságilag elmaradottabb régiók, kifejezetten a start-up vállalkozások és általánosabban a KKV-k. Az empirikus vizsgálatok kísérelik megragadni az állami beavatkozások tényleges hatását makro- és mikroszinten egyaránt. A vissza nem térítendő támogatások esetében azonban hiányzik egy olyan egységes, nemzetközileg is elfogadott módszertan, amely a támogatásban részesült vállalkozások gazdaságélénkítő hatásait képes számszerüsíteni. Ennek oka egyrészről az, hogy a banki finanszírozás értelmezése, módszertana és szabályozása egyértelmü, mialatt az állami támogatás fogalma nemzetközi értelmezésben meglehetősen sokrétü, illetve szabályozása és gyakorlata is eltérô. Az állam szerepe lehet a kimentés (bail-out), a nemzeti, regionális, illetve nemzetközi fejlesztési bankrendszeren keresztül kedvezményes hitel, garancia vagy tőke juttatása, valamint szabályozott körülmények között vissza nem térítendő támogatások nyújtása.

Tekintsük a következőkben az európai uniós vissza nem térítendő mikro-, kis- és középvállalatoknak nyújtott támogatásainak hatásmechanizmusát. A vállalkozás megvalósít egy fejlesztési projektet, amely esetében a termelési eszközök a valós bekerülési áron jelennek meg a 
könyvekben. A fejlesztési projekt esetében szeretnénk a társadalmi többletet kimutatni, ami azonban rejtve marad és csupán a teljes vállalkozás esetében tudjuk a gazdasági mutatókra gyakorolt hatást nyomon követni. Az utófinanszírozott vissza nem térítendő támogatási összeget elhatárolják a kifizetés időpontjában, amelynek az adott évre eső részét a vállalkozások a fenntartási időszakban egyéb bevételként elszámolhatják. Ezzel a vissza nem térítendő támogatásban nem részesült és hasonló méretű projektet megvalósító versenytárssal összehasonlítva a nyereség is növekedni fog, amely az eredménytartalék növekedésén keresztül a saját tőke értékét fogja emelni. A társadalmi többlet megjelenési formája a támogatásban részesített vállalatok saját tőkéjének növekedése ${ }^{3}$, amely a forgóeszköz-állomány növekedésében materializálódik, azaz megtakarításként, bankbetétként jelenhet meg, ezáltal önerőt képezve egy következő fejlesztési projekthez. A támogatás tehát egy jelentős hozzájárulás a vállalkozás következő fejlesztési projektjéhez, illetve beruházásához, amelyhez a saját erő értékét, éppen a megnövekedett profitabilitás következtében gyorsabban képes összerakni.

Az európai uniós támogatási politika elfogadja és megengedi a mikro-, kis- és középvállalkozások közvetlen állami támogatását, amelyet egy transzparens közvetítőrendszeren keresztül, versenysemlegesen biztosít az egyes tagországokban (1. táblázat). zése után megfigyelhető állapotot kell tekintenünk, hiszen az mutatja a teljes társadalmi hasznosság növekedését. Az egyes vállalkozások egyéni hozzájárulása a társadalmi hasznosság növekedéséhez, azaz a gazdasági teljesítmények javulásának eloszlása nem vizsgálati kérdés ebben a környezetben. Az a vállalkozás, amely a vissza nem térítendő támogatásért cserébe a vizsgált időperiódusban még nem tudott társadalmi hasznosság növekedést adni, elképzelhető, hogy néhány év múlva már képes lesz erre. A hatékonyság növekedése, azaz a tőke- és eszközarányos, illetve az egy alkalmazottra jutó bevétel, exportbevétel, nyereség nem ragadja meg jól a társadalmi hasznosság növekedését. Ezek a mutatók inkább a támogatásban részesült vállalkozások gazdálkodásának változását képesek bemutatni.

\section{A támogatási politika hatásmechanizmusa}

A vissza nem térítendő állami támogatást a vállalat egy pályázati eljáráson keresztül kapja meg, amelynek célja a megfelelőség és szakszerüség adminisztratív vizsgálata. A támogatási kérelem jóváhagyó elbírálását követően van lehetőség a támogatási szerződés megkötésére, amelyben egy olyan biztosíték szerepel, hogy amennyiben a vállalkozás a fenntartási időszakban nem folytatja a vállalt tevékenységet, akkor a támogatási összeget viszsza kell fizetni, és amennyiben a vállalkozás ennek nem tenne eleget, akkor a felajánlott fedezetből lehetséges a

1. táblázat A hazai támogatások megoszlása

\begin{tabular}{|c|c|c|c|c|c|c|c|c|}
\hline Évek / Támogatási célok & 2009 & 2010 & 2011 & 2012 & 2013 & 2014 & 2015 & 2016 \\
\hline Regionális fejlesztések & 342,0 & 284,7 & 241,6 & 273,1 & 319,7 & 839,5 & 426,7 & 760,4 \\
\hline$K K V$-szektor közvetlenül & 29,2 & 13,8 & 16,0 & 6,7 & 10,5 & 139,6 & 120,6 & 29,7 \\
\hline Teljes hazai támogatási kifizetések & 1339,7 & 2067,4 & 1204,1 & 1193,8 & 1495,2 & 1685,6 & 1443,7 & 2391,6 \\
\hline
\end{tabular}

Értékek millió euróban

Forrás: EUROSTAT

A kisvállalkozások támogatások, kedvezményes kamatozású hitelek, illetve pénzügyi garanciák formájában is részesülhetnek uniós finanszírozásban. A támogatás vissza nem térítendő pénzügyi segítséget jelent, míg a finanszírozás egyéb formái a fejlesztési célú bankrendszer ismert termékötleteiből származtak. Nemzetgazdasági szinten, a vállalkozások gazdálkodási adatainak összeg- támogatói igények kielégítése. Amennyiben a fenntartási időszak véget ér, akkor a vállalatnak többé már nincs kötelezettsége a támogató szervezetekkel. Ez alapján arra következtethetnénk, hogy a kereskedelmi banki finanszírozás és az állami támogatás meglehetősen hasonló vállalati forrásbevonási lehetőségek, csak a támogatás lényegesen olcsóbb.

\footnotetext{
${ }^{3}$ A támogatás hatékony felhasználása esetében a támogatási periódus végére a korábban elhatárolt, majd egyéb bevételként figyelembe vett támogatási összeg a megnövekedett eredményen keresztül a saját tőkében jelenik meg, amelyet még tovább növelhetnek a projekt pozitív hatásaként értékelt további eredménynövekedések is.
} 
Az állami támogatás eredményjavító hatása az amortizációs időszakban a beruházás értékcsökkenésének és a támogatás intenzitásából számolható ki, amely a korábbi elhatárolásból felszabadítva egyéb bevételként jelenik meg. Példaként egy öt éves amortizáció mellett, ötvenmillió forint vissza nem térítendő állami támogatás, évente tízmillió forinttal növeli meg az eredményt, minden egyéb feltétel változatlansága mellett. Nemzetgazdasági szinten azt figyelhetjük meg, hogy a KKV-szektor az európai uniós vissza nem térítendő támogatások révén többletforráshoz jutott. Ezek alatt a ROP és GINOP (korábban GOP) programokat értjük, amelyek esetében megvizsgálható az erkölcsi kockázat megjelenése a vállalatok gazdálkodásában, amelyhez a támogatások számviteli elszámolása és a gazdaságfejlesztésre gyakorolt hatásainak vizsgálata során azokat a nyilvánosan elérhető gazdasági adatokat tekinthetjük, amelyeket a vállalkozások minden évben a kötelező adatszolgáltatás keretében megadnak ${ }^{4}$.

Az állami támogatás javítja a vállalat eredményét az amortizációs időszakban, azonban még kérdés, hogy minden egyéb feltétel változatlanul hagyása mellett, miként alakult volna a vállalkozás jövedelemtermelő képessége. A vállalkozás tulajdonosa a közvetlen állami támogatás juttatása során olyan jövedelemtranszferben részesül, amelynek hatása a következő elméleti lehetőségek egyikében ragadható meg a folyósítás első éveiben:

(i) a vállalkozás nyereséges lenne, és a közvetlen állami támogatás eredményjavító hatása következtében a vállalkozás még nyereségesebbé válik,

(ii) a vállalkozás veszteséges lenne, de a közvetlen állami támogatás eredményjavító hatása következtében a vállalkozás nyereségessé válik,

(iii) a vállalkozás veszteséges lenne, és a közvetlen állami támogatás eredményjavító hatása következtében is veszteséges marad a vállalkozás.

A közvetlen állami támogatás eredményjavító hatása számvitelileg a következő módon érvényesül: amennyiben a támogatási szerződésben a meghatározott cél az eszközvásárlás vagy egy bevételnövekedés elérése, a vissza nem térítendő forrást egyéb bevételként kell elszámolni, arra az időszakra, amennyi a fenntartási időszaka a támogatásnak. Ez azonban kizárólag a mérleg forrásoldalának változását magyarázza, az eszközoldal, azaz a betétállomány értékének alakulása nem vezethető le belőle. A betétállomány a pályázat benyújtásának évében azt kumulált cash flow-értéket adja meg, amely a vállalkozás korábbi években felhalmozott szabad pénzeszközeiböl áll.
Vajon számolhatunk a KKV-k esetében hasonló következményekkel, mint a TARP-program ${ }^{5}$ esetén megfigyelt erkölcsi kockázat (Sheng, 2016). Amennyiben a vállalkozás ugyan elfogadja az állami támogatást, de ezt azért teszi, hogy ezzel helyettesítse a fejlesztési célú beruházás forrásigényét, és a megmaradt saját forrást bankbetétbe helyezze, akkor kettes típusú erkölcsi kockázatról beszélhetünk. A kérdés az, hogy ez vajon egy speciális esete az erkölcsi kockázatoknak, amelyben a vállalkozás elfogadja a vissza nem térítendő támogatást, és azt az egyéni hasznosság növelésére fordítja úgy, hogy a rendelkezésre álló saját forrás helyett a vissza nem térítendő támogatásból valósítja meg a fejlesztést.

Amennyiben a vállalkozás bár rendelkezésére áll, de nem a saját forrásból finanszírozza a beruházását, hanem állami támogatásból, és a rendelkezésre álló saját forrást bankbetétbe fekteti, ez felveti a versenysemlegesség problematikáját. Amennyiben egy vállalkozásnak rendelkezésére áll a beruházás megvalósításához szükséges forrás, akkor a támogatás igénybevétele során egy egyszerü jövedelemtranszfer valósul meg, amivel adófizetői pénzből a vállalkozó privát hasznossága növekszik. Az európai uniós támogatások esetében az állam köteles kizárni a csalás lehetőségét és mindent megtenni annak érdekében, hogy a szerződések kellő szankciót tartalmazzanak. Az erkölcsi kockázat következtében megvalósuló társadalmi többlet csökkenését azonban a támogatási szerződések nem képesek hatékonyan kezelni.

A 2008-ban kezdődött gazdasági válság jelentős hatással volt a vállalkozások hitelállományának alakulására (Ivashina, 2010), azonban ennél figyelemre méltóbb és meglepőbb a vállalkozások megtakarításainak változása (Tash, 2016). Észszerü feltételezés, hogy a vállalkozások egy olyan befektetési formában tartják szabad pénzeszközeiket, amelyek egyrészt könnyen felszabadíthatók, másrészt biztosan megörzi az értékét, és végül nem igényel különösebb pénzügyi, illetve befektetési banki ismeretet. Ez utóbbinak azért van jelentős szerepe, mert a vállalkozások részéről a szabad pénzeszközeik befektetési szempontjából kockázatkerülő magatartást feltételezhetünk. Ezzel egyértelmüen a bankbetét tekinthető a legjellemzőbb formának. A hazai, nem-pénzügyi szektorba tartozó vállalkozások hitel- és betétállományának történelmi alakulását az 1. ábra szemlélteti. A hitelállomány esetében folyamatos csökkenés, míg a betétállománynál folyamatos növekedés figyelhető meg. A folyamat eredménye, hogy 2016 végére a betétállomány meghaladja a hitelek összesített értékét.

\footnotetext{
${ }^{4}$ Az európai uniós támogatások publikusak, a részletei megismerhetők itt: https://www.palyazat.gov.hu/tamogatott_projektkereso

${ }^{5}$ Az eredetileg 700 milliárd dollár értékben meghatározott Troubled Asset Relief Program a gazdaság stabilizálását szolgálta úgy, hogy kétes követelések megvásárlását tette lehetővé.
} 
1. ábra A hazai vállalatok hitel-betét állománya 2007-2017

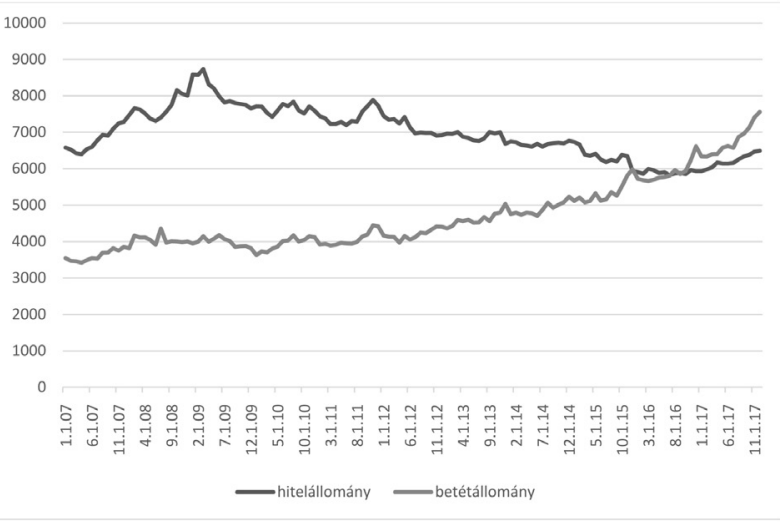

Milliárd forintban

Forrás: MNB

A hitelek csökkenése egyértelmü következménye a kereskedelmi bankrendszer reakciójának, éppen ezt a folyamatot jellemeztük a kontraszelekció, illetve az erkölcsi kockázat fogalmaival. A nemzeti gazdaságpolitikák válasza a vállalkozások hitelállományának folyamatos csökkenésének megállítására eltérő volt az európai uniós támogatási politikák nemzetállami manifesztációiban (Campello, 2010). A hazai megközelítésben a vissza nem térítendő támogatások játszottak fontosabb szerepet összehasonlítva a támogatott hitelekkel. A kedvezményes kamatozással kínált hitelek szempontjából a legfontosabb tényező a Magyar Nemzeti Bank által meghirdetett Növekedési Hitelprogram volt (MNB, 2017).

A kereskedelmi hitelek érzékelt kamata éppen a referencia kamatláb csökkenése következtében jelentősen mérséklődött. A hét éves tervezési ciklus kezdetén a jegybanki alapkamat ${ }^{6} 2007$ januárjában 8 százalék volt, amely a válság hatására 11,5 százalékig emelkedett 2008 végére, majd ezt követően folyamatosan csökkenve a 8 százalékos értéket 2009 augusztusára érte el. Néhány tíz bázispontot korrigálva három éven keresztül a 6-7 százalékos sávban mozgott, majd 2013 elejétől egyértelmű csökkenésbe kezdett. Ebben az évben mintegy három százalékpontot mérséklődött az értéke, majd az ezt következő két évben rendre egy-egy százalékpontot, amellyel 2016-ra 1\% alá került. Ez a támogatások vizsgálata során tekintett ciklus eléjéhez képest 7 százalékpont, a ciklus elején elért maximum értékhez képest több mint 10 százalékpont csökkenést jelent. Ez jól szemlélteti azt, hogy a támogatási politika intézményrendszerének terméke fokozatosan elönyt veszít, azaz a kedvezményes kamatozású hitelek relatív előnye a ciklus végére elfogyott. Amennyiben a kereskedelmi banki hitelek esetében a KKV-szektor irányába 4-500 bázispontos átlagos hitelfelárral számolunk, akkor az érzékelt kamatláb egyharmadára esett vissza. A kamatláb csökkenési üteme nem magyarázza egyértelműen a vállalati szektor hitelállományának folyamatos csökkenését..

Másoldalról a csökkenő betéti kamatok éppen nem támasztják alá, hogy a betéti állomány növekedjen. Tekintsük a következőkben a folyamat, a hitel-betét állomány különbségének alakulásának, 2007-2016 közötti időbeli lefolyását a 2. ábrán. A nettó pozíció a szélsőértékekhez képest 5,5 ezer milliárd forinttal csökkent, azaz hitelállomány csökkenésének és a betétek növekedésének kumulált hatása a vizsgált tíz éves ciklusban kiemelkedően magas volt.

\section{2. ábra A hazai vállalatok nettó hitel-betét pozíciója 2007-2017}

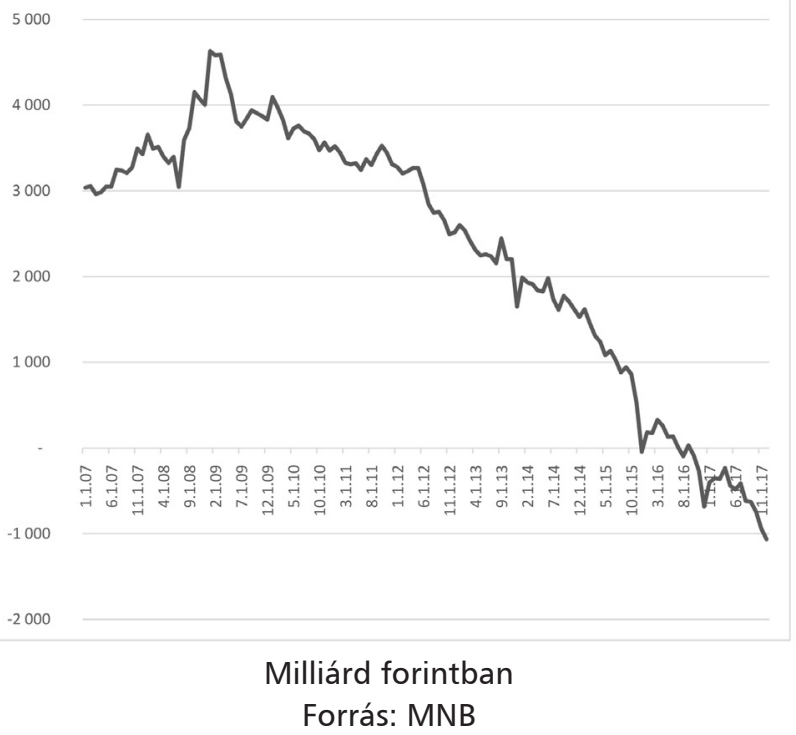

Elméletileg a vállalkozások betétállománya azért növekedhetett, mert a nyereséges müködés következtében a mérleg szerinti eredményen keresztül az eredménytartalék megnöveli a saját tőkét. A nyereség növekedése egyenes következménye a támogatás számviteli elszámolásának, azaz a projekt fenntartásának éveiben a támogatási összeget az amortizációs politika alapján több éven keresztül egyéb bevételként számolják el. A vállalkozás müködése során azonban a korábban megvalósított beruházások esetében a vissza nem térítendó állami támogatások közvetlenül nem növelik a betétek állományát, hiszen az utófinanszírozás során a támogatási intenzitás függvényében a beruházásnak csak egy részét kapják vissza a vállalkozások. A támogatási kifizetések közvetlenül nem magyarázzák a betétállomány növekedését. A betétállomány növekedése legvalószínübben a fejlesztési projekt megnövekedett jövedelemtermelö képességéből származhat. A vállalkozás, az utófinanszírozás következtében, a támogatási kifizetés időpontjára már megvalósított egy beruházást, és a támogatási összegek kifizetése utólag esedékes, illetve az értékcsökkenés értéke is magasabb, mintha nem történt volna beruházás. Amennyiben azt az esetet hasonlítjuk össze, hogy támogatásból egy nagyobb beruházást tudott megvalósítani a vállalkozás, akkor amennyiben a támogatási intenzitás mértékével növelte a beruházás méretét, akkor semleges a hatás, amennyiben ennél nagyobb mértékben, akkor rövid távon negatív, hosszú távon pozitív a hatás.

Az elszámolt értékcsökkenés a támogatási intenzitás mértékéig a támogatásban részesült projektek esetében

\footnotetext{
${ }^{6}$ Az értékek az MNB hivatalos közléséből származnak http://www.mnb.hu/Jegybanki_alapkamat_alakulasa
} 
beépült az eredménybe és ezen keresztül az eredménytartalékba is. A támogatási kifizetésben részesült projektek esetében az értékcsökkenés növekedésének támogatási intenzitással korrigált értéke, olyan egyéb bevételként, amellyel szemben nem számolunk el költséget, közvetlenül a nyereséget és az eredménytartalék értékét növeli meg. A betétállomány növekedése csak egy lehetséges következménye a sajáttőke értékének növekedésének, számos egyéb alternatíva is elképzelhető7.

Az összehasonlítások során mindig a teljes vállalati betétállomány változásához viszonyítjuk a támogatásban részesült vállalkozások betétállományának változását. A támogatást nem kapott vállalatok helyett a teljes vállalati populációt tekintjük, mint összehasonlítási alapot, hiszen egy évben nagyságrendileg tízezer vállalkozás kapott támogatási kifizetést, amely töredéke a több százezer vállalatnak, így élhetünk ezzel az egyszerüsítő feltétellel. A 3. ábrán a 2010 és 2014 közötti években az összehasonlításként választott év esetében az eggyel korábban támogatási kifizetésben részesült vállalkozások betétállományának növekedését hasonlítjuk össze a teljes vállalati populációval. Az egyes években azt tapasztaljuk, hogy a támogatott vállalkozások esetében nagyobb arányban nőttek a betétek, mint ez történt az összes vállalat esetében. Kiugróan jelentős a különbség a 2009-ben és 2012-ben támogatási kifizetésben részesült vállalkozások esetében, azaz a 2010-es és a 2013-as években a támogatott vállalati populáció rendre másfélszer, illetve több mint kétszer akkora növekedést mutatott, mint az összes vállalat együtt. A 2012-es évben betétállomány-növekedésben pedig nem arányaiban, hanem abszolút értékében teljesített jobban a 2011-ben támogatásban részesült vállalatok csoportja, hiszen 4,3\% százalékos növekedést értek el, mialatt a teljes vállalati betétállomány ennek közel egy tizedével, azaz 0,4 százalékkal csökkent. A vizsgált öt év közül kettőben, azaz 2011-ben és 2014-ben, tehát a 2010-ben és 2013-ban a viszsza nem térítendő támogatást megkapott vállalkozások 0,2 és 0,5 százalékkal múlták csupán felül az összes vállalat betétnövekedését, ami négy és hét százalékos abszolút értékekhez viszonyítva közel azonosságként is értelmezhető.

\section{3. ábra A betéti állományok növekedése 2010-2014}

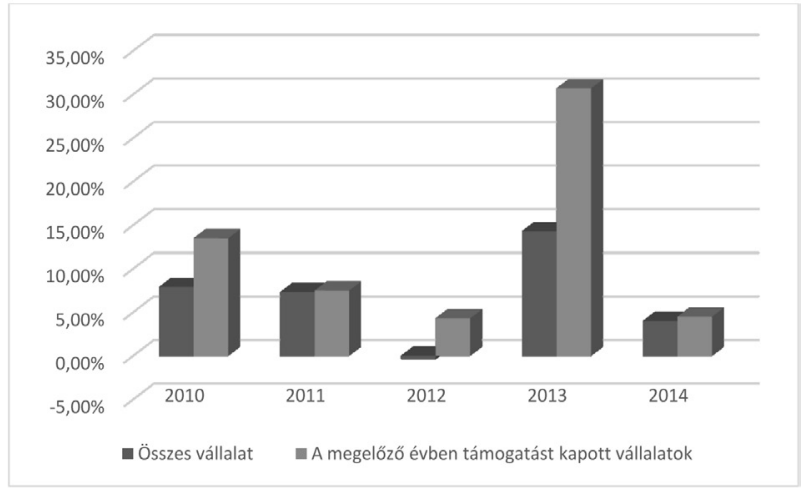

Forrás: saját gyűjtés, palyazat.gov.hu
A következőkben a 2015-ös évben hasonlítjuk össze a 2008 és 2014 közötti években támogatási kifizetésben részesült vállalkozások és a teljes vállalati populáció által mutatott betétállomány-növekedést. Megállapíthatjuk, hogy valamennyi, a korábbi években folyósított vissza nem térítendő támogatást kapott vállalat összességében nagyobb arányban volt képes a betéti állományát növelni, mint a vállalatok összessége (4. ábra).

4. ábra A betéti állományok növekedése 2015-ben a korábbi években támogatási kifizetésben részesedett vállalkozások összehasonlítása

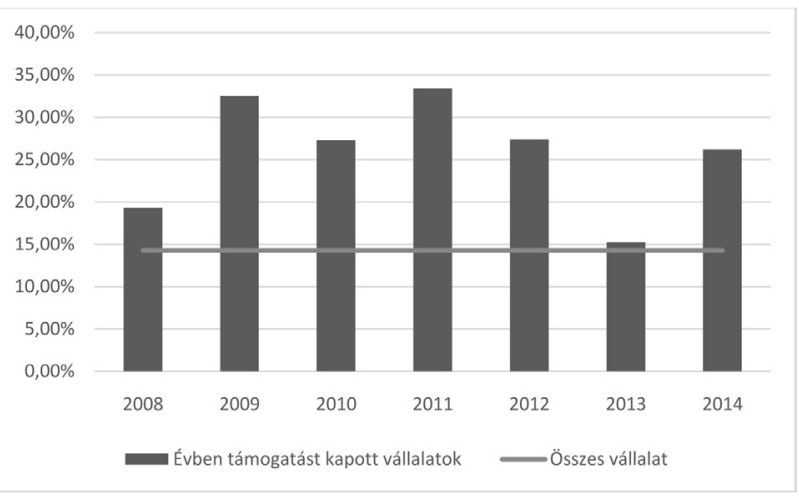

Forrás: saját gyűjtés, palyazat.gov.hu

A támogatásban részesült vállalkozások azért tudták gyorsabban növelni a betéteket, mint a vissza nem térítendő támogatást nem kapott vállalkozások, mert a fejlesztési projektek során megvalósított beruházások értékcsökkenése, amely nem pénzbeli költség, hatással volt a vállalkozás szabad pénzállományára is. Tehát a betéti állományok gyorsabb növekedése a támogatott vállalkozások esetében a megnövekedett nyereségesség és versenyképesség következménye és nem az erkölcsi kockázat megjelenése.

\section{Összegzés}

Megállapíthatjuk, hogy a támogatásban részesült vállalkozások nagyobb mértékben járultak hozzá a vállalati betétállomány növekedéséhez, ami a támogatásban részesült vállalkozások feltételezhetően jobb és javuló gazdasági teljesítménye következtében lehetséges. Arra következtethetünk, hogy a betétállomány növekedése a támogatási kifizetésben részesült vállalkozások esetében nem azért történt, mert a támogatási kifizetéseket a betétállomány növelésére fordították, és ezáltal az egyéni hasznosságukat növelték, hanem a betétállomány gyorsabb növekedése következménye és nem velejárója volt a támogatásoknak. A vissza nem térítendő támogatás következtében a vállalkozásnak megnövekszik az árbevétele, mert a fenntartási időszakban a korábban elhatárolásként szerepeltetett támogatási összeget folyamatosan felszabadíthatják és egyéb bevételként elszámolhatják. Ezzel a vissza nem térítendő támogatásban nem részesült és hasonló méretű projektet megvalósító versenytárssal öszszehasonlítva a nyeresége is növekedni fog. A vállalkozás

\footnotetext{
${ }^{7}$ Növekedhet többek között a befektetett eszközök vagy a készletek, illetve csökkenhet a kinnlevőségek, a szállítók, a hitelek állománya.
} 
szempontjából pozitív hatása van a vissza nem térítendő támogatásoknak, hiszen megvalósíthat egy fejlesztési projektet, amely esetében a termelési eszközök a valós bekerülési áron jelennek meg, de ezért ténylegesen a támogatási öszszeggel kevesebbet fizet. A megvalósított fejlesztési projekt esetében a vezetői információs rendszerben elkészített kimutatások során a termelésben részt vevő eszközök bekerülési értékének csökkenéseként is elszámolhatjuk a vissza nem térítendő támogatásokat, azonban a vállalkozások által készített pénzügyi jelentések esetében a támogatás közvetlen eredményjavító tételként jelenik meg, amely az eredménytartalék növekedése révén magasabb saját tőkéhez vezethet. A társadalmi többlet meghatározásánál a teljes vállalkozás esetében tudjuk a gazdasági mutatókra gyakorolt hatást nyomon követni, amely a megnövekedett eredmény és a javuló tőkehelyzet, amelyhez párosul a betétállomány növekedése is, azaz ebben az esetben nem beszélhetünk az erkölcsi kockázat egy új típusáról, illetve a betétállomány növekedése nem azonosítható az erkölcsi kockázat megjelenéseként.

A vissza nem térítendő támogatási kifizetésben részesült vállalkozások összességükben növelték a társadalmi többletet, azonban az egyes vállalkozások esetében eltérő eredményre is juthatunk. Amennyiben a támogatásban részesült vállalkozások saját fejlesztési forrásai elegendők lettek volna a támogatási kifizetések nélkül is a fejlesztési projektet megvalósítani, akkor a véglegesen átadott pénzeszköz tovább növelte a vállalkozás nyereségét és javította tőkehelyzetét. Amennyiben a megvalósított fejlesztés pozitív hatással volt egy iparág, régió, illetve fogyasztói csoport tagjaira, akkor társadalmi többlet is keletkezett. A további kutatások során az erkölcsi kockázat megjelenésének egyéb formáit szükséges azonosítani, az előbbiekben a betétállomány növekedéséről megmutattuk, hogy az nem tekinthető annak.

\section{Felhasznált irodalom}

Banerjee, A., \& Duflo, E. (2004). Do firms Want to Borrow More: Testing Credit Constraints Using a Directed Lending Program. Cambridge, MA: Massachusetts Institute of Technology. Processed.

Beck, T. (2007). Financing constraints of SMEs in developing countries: Evidence, determinants and solutions. KDI 36th Anniversary International Conference.

Berger, A. N., \& Udell, G. F. (2006). A more complete conceptual framework for SME finance. Journal of Banking \& Finance, 30(11), 2945-2966.

Berlinger, E., Lovas, A. \& Juhász, P. (2016). State subsidy and moral hazard in corporate financing. Central European Journal of Operations Reserach, December, Volume 25, Issue 4, 743-770.

Berlinger, E., Juhász, P., \& Lovas, A. (2015). Az állami támogatás hatása a projektfinanszírozásra erkölcsi kockázat és pozitív externáliák mellett. Közgazdasági Szemle, 62(2), 139-171.
Campello, M., Graham, J. R., \& Harvey, C. R. (2010). The real effects of financial constraints: Evidence from a financial crisis. Journal of Financial Economics, 97.3, 470-487.

European Comission. dátum nélk. European commision. (n.d.). http://ec.europa.eu/competition/legislation/treaties/ec/art88_en.html.

Griffith-Jones, S., Tyson, J., \& Calice, P. (2011). The European Investment Bank and SMEs: Key Lessons for Latin America and the Caribbean. Santiago, Chile: ECLAC.

Holmstrom, B., \& Tirole, J. (1997). Financial intermediation, loanable funds, and the real sector. The Quarterly Journal of Economics, 112(3)., 663-691.

Ivashina, V., \& Scharfstein, D. (2010). Bank lending during the financial crisis of 2008. Journal of Financial Economics, 97(3), 319-338.

Kállay, L. (2014). Állami támogatások és gazdasági teljesítmény: Támogatás-túladagolás a magyar gazdaságfejlesztésben? Közgazdasági Szemle, 61(3), 279-298.

MNB (2017). https://www.mnb.hu/letoltes/a-novekedesihitelprogram-eredmenyei-honlapra-20170613.pdf.

OECD (2015). OECD SME and Entrepreneurship Outlook 2005. Paris, France: OECD Publishing.

Petersen, M. A., \& Rajan, R. G. (1995). The effect of credit market competition on lending relationships. The $Q u$ arterly Journal of Economics, 110(2), 407-443.

Repullo, R., \& Suarez, J. (2013). The procyclical effects of bank capital regulation. Review of Financial Studies, 26(2), 452-490.

Repullo, R, \& Suarez, J. (2000). Entrepreneurial moral hazard and bank monitoring: a model of the credit channel. European Economic Review, 44(10), 1931-1950.

Stiglitz, J. E., \& Weiss, A. (1981). Credit rationing in markets with imperfect information. The American Economic Review, 71(3), 393-410.

Stiglitz, J. E., \& Weiss, A. (1987). Credit rationing: reply. The American Economic Review, 77(1), 228-231.

Sheng, J. (2016). The Real Effects of Government Intervention: Firm-Level Evidence from TARP. 2014 North American Summer Meeting of the Econometric Society, 2014 Northern Finance Association Conference. Available at SSRN: https://ssrn.com/abstract=2702672 or http://dx.doi.org/10.2139/ssrn.2702672

Tash, F. H., \& Egle, K. (2016). Motives for Entrepreneurial Saving: Evidence from Sweden. Swedish House of Finance Research, Research Paper No. 15-17

Tirole, J., \& Farhi, E. (2009). Collective Moral Hazard. Maturity Mismatch and Systemic Bailouts. The American Economic Review, 102(1), 60-93.

Vives, X. (2010). Competition and stability in banking. CESifo Working

Paper, No. 3050. Munich, Germany: Center for Economic Studies and Ifo Institute (CESifo). 